\title{
Decomposed: a political ecology of music
}

\section{DRAFT OF ARTICLE PUBLISHED IN POPULAR MUSIC (2015)}

\begin{abstract}
This article is about what recordings are made of, and about what happens to those recordings when they are disposed of. It inscribes a history of recorded music in three main materials: shellac, plastic and data. These materials constitute the five most prevalent recording formats since 1900: 78s, LPs, cassettes, CDs and MP3s. The goal is to forge a political ecology of the evolving relationship between popular music and sound technology, one which accounts not only for human production and consumption but also material manufacture and disposal. Such an orientation is useful for developing an analytical framework that is adequate to the complexities of the global material-cultural flows in which the recorded music commodity is de/constituted. It also strives toward a more responsible way of thinking about the relationship between popular music's cultural and economic value, on the one hand, and its environmental cost, on the other.
\end{abstract}

\section{Introduction}

Modern development, consumption and waste have strained the environment to the point of crisis - and music is part of the problem. Consider the poisonous petrochemicals used to manufacture LPs, the non-biodegradable plastics in CDs, the energy-guzzling server farms that power streaming MP3s, and the toxic graveyards of obsolete consumer electronics around the world. But these earthy and potentially ugly material realities typically go unnoticed in musical discourse, probably because they clash with a longstanding but mistaken belief that music is somehow an immaterial phenomenon. Indeed, even though we are accustomed to the accusation that certain types of music are 'disposable', we rarely think about what happens to recordings when they are actually disposed of. And while commonsense tells us that the 'music industry' is in the business of making records, we rarely think about what those recordings are actually made of. Correspondingly, the environmental impact of recorded sound is almost completely 
unaccounted for in cultural studies of music and media, which treat the musical commodity principally as a product of musical labour, an object of capitalist exchange, or a text for audience consumption. Questions about the actual material composition and decomposition of the musical commodity — about what happens to music before production and after consumption — have been largely ignored. Yet without confronting the relationship between music's cultural and economic value, on the one hand, and its environmental cost, on the other, the field of music studies forfeits the opportunity for a fully interdisciplinary engagement with — and a holistic democratic ethics of — its object of study. One step toward achieving that goal is to formulate a political ecology of the evolving relationship between popular music and sound technology since 1900.

This article inscribes a history of recorded music in three main forms of materiality: shellac (1900-1950), plastic (1950-2000) and data (2000-present). These three broad phases in the material history of recorded music correspond to this article's three main sections. They also encompass the five most prevalent recording formats since 1900: $78 \mathrm{~s}$ (shellac); LPs, cassettes and CDs (plastic); and MP3s (data). I subject these three materials to a double-headed investigation, examining the dynamics of manufacture and obsolescence that mark the shifts between them. As a backdrop to the sections on shellac, plastic and data, the article begins by outlining what a political-ecological approach to recorded music might look like, and what it might offer. The overarching aim is to present a preliminary account of the global material-cultural flows in which the recorded music commodity has been de/constituted.

\section{Political ecology and recorded music}


Political ecology is multifaceted and difficult to summarise (cf. Hayward 1994, Robbins 2012, Neumann 2014). At a basic level, though, political ecology is defined by critical attention to the principles of action and forms of social order that link material environments and human cultures. Political ecologists demonstrate a particular interest in the environmental stresses that result from resource extraction and processing, as well as product manufacturing, consumption and disposal. From this perspective, a political ecology of music would study how the stuff of musical culture is made and possessed, dispossessed and unmade.

Although a political-ecological approach could be applied to any aspect of music's material culture — such as sheet music, instrument manufacturing, concert-going — my particular interest is in recordings. ${ }^{1}$ Just as political ecology is heterogeneous, so are there numerous existing ways of thinking about recordings as items in the world: as commodities, technologies, media, formats, objects, emblems, things, et cetera (e.g. Kenney 1999, Kittler 1999, Straw 1999-2000, Maisonneuve 2001, Born 2005, Hennion 2007, Sterne 2012). There are also plenty of ways to think about how such items come to be and move through musical culture: production, consumption, distribution, reception, exchange, attachment, mediation, circulation, and so on (e.g. Jones 2002, Ochoa and Botero 2009, Straw 2010, Toynbee and Dueck 2011, Born 2012, Novak 2013, Santoro 2015). What's more, there are various frameworks for conceptualizing the connections that are enacted between people and materiality in the creation and circulation of cultural artifacts more generally (e.g. Thompson 1979, Brown 2001, Pels et al. 2002, Gaonkar and Povinelli 2003, Latour 2005, Miller 2005, Appadurai 2006, Suchman 2007, Bennett 2010, Born 2010, Coole and Frost 2010, Ingold 2012, Barry 2013, Sterne 2013). In 
combining aspects of many of these perspectives, the goal here is to highlight the coformative associations of biology, geology, capital and culture that animate the social life (Appadurai 1986) and social death (Gabrys 2011) of recorded music artifacts. Building on both this diverse range of literature and the above definition of political ecology, it is possible to offer a more precise conception of a political-ecological approach to music.

On the side of making and possession, a political ecology of music has an interest in the movement and processing of materials that are required before a recording can be bought or sold, created or listened to. There is a whole economy of raw materials and supply chains that undergird what is traditionally called the recording industry. This economy is able to mobilize and synchronize massive, global aggregations of people and materials, intertwining numerous national governments, local economies and environments. While such processes and materials may seem peripheral, they are actually central to what the recording industry is and how it works.

On the side of unmaking and dispossession, political ecology is interested in how even our favourite recordings, like all good things, must come to an end. That is, recordings eventually enter into circuits of dispossession (cf. Lucas 2002). Here, one mode of accumulation (as an expression of fandom) gives way to another (as a measure of disinterest): where we once collected records, our records now collect dust. And when the value of billions of such recordings is truly exhausted (Straw 2000), the question becomes: where do they go? Political ecology is here interested in waste, in the sense of both the ravages of production and the remnants of consumption.

Thus, the issue for the political ecologist is more than who is making and listening to music, or buying and selling it — or even what that music sounds like. ${ }^{2}$ Political 
ecology is also about where the raw materials of musical artifacts come from and how they are processed and manufactured, as well as how the artifacts are treated and where they go when we are done with them.

The potential contribution of a political ecology of music seems twofold. Analytically, for music studies, the approach offers an expanded conception of musical culture. This approach highlights more fully the global reach and power of the music industries. It asks how the aesthetic and industrial circulations of musical culture hinge on the material and economic flows of resource networks. It considers dispossession not merely as an afterthought or an adjunct to ironically linear models of product lifecycle (cf. Gregson and Crang 2010, Lepawsky and Mather 2010) but, rather, as part of a topology of musical materiality in which the question of disposal is immanent in desire and manufacturing, in which 'afterlife . . . is anticipated before exchange' (Hawkins 2013, p. 51; cf. Lury et al. 2012). In other words, if research into consumption and possession has revealed much about music as an agent in social life (e.g. Peterson 1992, DeNora 2000, Bull 2007, Savage and Gayo 2011; cf. Bourdieu 1984, Bennett et al. 2009), then so might rituals of disposal and dispossession reveal various social logics and inform our understanding of musical culture (e.g. Straw 1999-2000; cf. Strasser 1999, Lucas 2002, Hetherington 2004, Hawkins 2006). Together, these ways of looking at musical culture call for "a change in focus, from the "objectness" of things to the material flows and formative processes wherein they come into being' (Ingold 2012: 431) — and wherein they cease to be. A simple way of thinking about a political-ecological approach is as an expanded and radically material "art world" (Becker 1982): If coffee porters matter in the world of literature, then so do farmers, chemical engineers and waste workers in the 
world of music.

Implicit in the above is a second potential contribution of political ecology: a relatively new avenue of critical social engagement for music scholarship. Policy is an established and, it seems, increasingly important issue in popular music studies (Cloonan 2007, Stanbridge 2007, Frith 2012, Street 2013, Behr 2015). Such work rightly focuses on difficult questions of cultural 'value' and attendant arts funding issues in the face of the continued hardening of neoliberal economic philosophies. A radically material approach to music may add to the political relevance of music studies by spurring scholars to look at the place where music's economic and cultural significances encounter its environmental consequences, thus opening the door to critical interventions at the intersection of music, media and environmental policy (cf. Bottrill et al. 2008). The issue, then, is one of making us more aware as scholars, musicians and listeners - and thus more responsible, too.

In these ways, a political ecology of music is somewhat different than other existing 'ecologies' of music. It is not the naturalistic and aesthetic 'environmentalism' that defines the acoustic ecology of R. Murray Schafer (1994) and Barry Truax (2001). Nor is it the perceptual-ecological framework that defines the social psychologies of Eric Clarke (2005) and Tia DeNora (2011). The politics of political ecology are most closely aligned with ecomusicology (Rehding 2002, Grimley 2006, Guy 2009, Ingram 2010, Allen et al. 2011, Echard 2011, Pedelty 2012). Yet my relative inattention to the musical imagination and its semiotics of landscape seems to differentiate my approach from the hermeneutics of ecology that prevails in that field (for exceptions see Ingram 2007; Allen 2012; Pedelty 2012, pp. 17-36). While I assume that a political ecology of music is a 
partner to ecomusicology, in methodological terms this project is more closely connected to a literature that complements a longstanding emphasis on what happens when old media were new (Marvin 1988) by examining what happens when new media grow old (Acland 2007). It is also closely connected to an emerging style of media ecology, which is not the study of 'media environments' after Marshall McLuhan and Neil Postman (cf. Lum 2006) but, rather, the study of how the manufacture and delivery of mediated culture 'consumes, despoils, and wastes natural resources' (Maxwell and Miller 2012, p. 1; cf. Gabrys 2011, Acland 2014, Parikka 2014, Parks and Starosielski 2015). ${ }^{3}$ Perhaps, from these perspectives, the term 'geomusicology' would more accurately describe my approach to the material politics of recorded music.

With varying degrees of explicitness and implicitness, the rest of the article kneads its three main materials into this political-ecological framework, moving through shellac, plastic and data. The effect of organising the article in this way is not necessarily a cumulative argument. Rather, it is to cover some largely uncharted territory, or to recover and re-chart a territory that has been mapped in other ways, so that several themes can emerge and recur. First, the article consistently highlights industries such as natural resource extraction, chemical engineering and energy production, none of which are normally seen in music scholarship as integral to the business of making records. Indeed, whereas it has been necessary to distinguish cultural commodities from other kinds of goods and services (Miège 1979), and to examine music's specificity within that subcategory (Straw 1999-2000, Taylor 2007a, Morris 2010), this article suggests that conceptualisations of the recorded music commodity also stand to gain from reconnecting the artifact with its baser but not exactly 'raw' materials (cf. Barry 2005, Bennett 2010, 
Ingold 2012). Second, practices of production, consumption and accumulation are seen, not quite as versos, but as topological functions of waste, construed broadly to include fallout from production (Murphy 1994), rituals of dispossession (Lucas 2002), renewal through wrecking and recycling (Lepawsky and Mather 2010) as well as plain old garbage (Maxwell and Miller 2012). Finally, in moving roughly chronologically from shellac to data, I do not mean to imply a teleology in which materials replace one another in a succession of improvements on the way to 'perfect fidelity'. This article views the history of sound reproduction less in terms of the continuous progress of technology than the contingent practicalities of political ecology.

\section{Shellac}

In the early days of commercial sound reproduction, recordings came in all shapes and sizes, spun at various speeds, and were made from all kinds of stuff — from household tinfoil to high-tech Condensite, beeswax to beef tallow, celluloid to spermaceti. ${ }^{4}$ As early as 1895 , though, the race to mass duplicate recordings led Emile Berliner to use a composite shellac formula in his discs. The combination of the disc form and the shellac formula was preferred, not only to Thomas Edison's cylindrical phonograph recordings, which were at the time made of vulnerable wax, but also to the hard vulcanite rubber then used in pressing discs, which was prone to warping (Read and Welch 1976, p. 127). With the arrival of electrically powered turntables in the 1920s, the speed of recordings was standardised at 78 revolutions per minute..$^{5}$ In these ways, the shellac $78 \mathrm{rpm}$ disc became the key material form of recorded sound for nearly half the history of commercial sound reproduction. 
Shellac is a resin made from lac, the sappy secretion of a beetle native to southern and eastern Asia. Twice a year these insects swarm 'like blood-red dust' in the forests of India and Thailand, and twice a year the twigs they encrust with lac are harvested, crushed, washed, dried, melted and 'made into thin sheets which are broken into the familiar flakes of the shellac of commerce' (Walker and Steele 1922, p. 278). Although the modern shellac trade began in the late nineteenth century (Anon 1913) and although shellac was used in everything from varnish and buttons to poker chips and electronics components (Walker and Steele 1922, p. 280), it was the popularity of the gramophone record that fuelled the explosion of the shellac industry after 1900.

The demand for shellac during these years was such that producers struggled to keep up. As a result, prices varied and the quality of the supply was uneven: 'Often it was loaded with impurities such as grass, weeds, gravel, plain dirt, and it seemed, anything else that would add weight to the shipment' (Isom 1977, p. 719; cf. Parthasarathi 2005, p. 29). What's more, the First World War and its aftermath saw the price of shellac jump from $£ 8$ per 100 kilograms to over $£ 50$ by 1921 (Martland 2013, pp. 201, 271), partly because of scarcity due to the use of shellac in anticorrosive paint on Naval ships (Walker and Steele 1922, p. 280). The upshot of this inflation was that the record industry used lower quality shellac, less virgin shellac and less total shellac per disc, which resulted in rougher records (both in terms of acoustic definition and needle wear-and-tear). Still, the postwar boom in consumer demand was enough to offset the overall rise in price (Martland 2013, pp. 210, 271, 276) and shellac maintained its centrality until about 1950. By then, shellac production in India peaked at 40 million kilograms per year - the majority of which went to record companies. ${ }^{6}$ 
While that amount of resin could go a long way in the recording industry, yielding about 300 million discs, it took millions of beetles about a year to produce a single kilogram of the stuff. ${ }^{7}$ Given average shellac yields (Singh 2007) that level of production would have required around 100,000 hectares of land. ${ }^{8}$ When we consider that billions of discs were manufactured during the half-century long shellac era, this raises questions about the environmental consequences of such activity. ${ }^{9}$ The process of protecting crops, for example, can involve the use of toxic pesticides. Further, while harvesting techniques (which basically involve sawing, striking and scraping tree branches) could be could be 'painstaking and selective', they were often 'gross and ravenous' (Isom 1977, p. 719). This could lead to the death of host trees. That said, the rapid lifecycle of the lac beetle is such that shellac is a renewable resource. In these ways, commercial shellac cultivation and harvesting shares in many of the controversies that mark forestry and agribusiness writ large.

Key as shellac was to the political ecology of early recorded music, the resin was actually a minority ingredient in gramophone discs. The majority of these records - up to 85 percent - consisted of filler, a mixture of minerals, fibers and lubricants in which shellac acted as a binding agent. The chief fillers were crushed slate and limestone, mixed in equal parts. Limestone was particularly important not only because it was inexpensive (so was slate) but because it was smooth; it sounded better, flowed well under the needle. This junction between the acoustic signature of limestone and its price point is one among many instances in which the contours of the history of recorded music, as an aesthetic form, have developed in tandem with the material politics of resource networks. 
The best and most limestone came from Indiana. It was partly for this reason, remembered RCA engineer Rex Isom (1977, p. 720), that in the late 1930s RCA Victor moved a significant portion of its production facilities to Indianapolis. Columbia followed suit, and to this day places like Terre Haute, Indian remain important manufacturing centres in the recording industry. Isom (ibid.) noted that 'the advantages of being near the source of the best filler ... showed up larger than was expected on the bottom line of the balance sheet'. But the RCA engineer's cost-benefit analysis does not consider the ecology of limestone extraction, which is infamously destructive of landscape, habitat and water supplies. From this perspective, using 'shellac' as shorthand for the 78-rpm record is actually something of a misnomer. The critical ecosystems for $78 \mathrm{~s}$ were as much the quarries of Indiana as they were the forests of India.

The various constituent materials of 78 s converged, mixed and took shape in pressing plants. With their smoke stacks, assembly lines and heavy-duty machinery, these plants were obvious sites of standardisation, mass production and industrialisation. Although recording was not the first instance of mass musical production (precedents can be found in the sheet music and instrument trades) there is a sense in which music had not been seen as an 'industry' before sound recording (Eisenberg 2005, p. 18). Indeed, coupling of music and industrialisation was a target of cultural critique. As Richard Osborne (2012, pp. 70-71) notes, René Claire offered a cinematic comparison between the 'prison regime and the production line in a gramophone factory', while Theodor Adorno derided the resemblance of gramophone production to the progressive assembly of the Ford Model T. George Orwell, for his part, noticed the record industry's potential for environmental damage and complained gracefully about a 'Ruined Farm near the His 
Master's Voice Gramophone Factory'. Still, what these critics of musical industrialisation do not consider are the less obvious ways that the recorded music industry also began as part of various natural resource industries.

The political-ecological history of the 78-rpm disc thus highlights seemingly unlikely connections between the industries of music, forestry and mining. Such relationships were not incidental; they were integral to the everyday operations of making and selling recorded music. To understand how the price and availability of raw materials influenced business decisions is to appreciate more fully how the record industry functions as an industry. What's more, to observe the import-export patterns of feedstocks such as shellac and limestone is to extend back the timeline of musical globalisation, past the debates about 'world music' that emerged in the 1980s. Similar points have been made by others, albeit in relation to hybrid aesthetic and identity formations (Kassabian 2004, Taylor 2007b) and, implicitly, transnational movements of musical commodities as finished products (Gronow 1983). Together, these emphases have defined the study of musical globalisation as the study of what Keir Keightley (2011) perceptively calls 'song networks'. But there are other factors at play. To paraphrase Arjun Appadurai (1986, p. 13), although the biographical aspect of some things (such as 78s) may be more noticeable (because they garner more symbolic investment) than that of some others (such as shellac and limestone), these other materials are no less important. Indeed, the industrial-aesthetic textures of song networks take shape in relation to the industrial-material flows of resource networks. The political-ecological viewpoint thus shifts not only the timeline of musical globalisation but also the character of the questions that can be asked about the phenomenon. In this 
way, the 78 era is part of a longer history of musical globalisation — a history which is not only about the movement of recordings around the Earth but also the movement of earth to make recordings.

\section{Plastic}

The dominance of the 78 format was doubly challenged in the late 1940s, with the introduction of Columbia's 331/3 rpm 'long play' (LP) album and RCA-Victor's 45 rpm 'single'. Following a drawn out 'war of the speeds', in which LPs and 45s jockeyed for position both between themselves and with 78s, the LP was crowned the 'core commodity' of the western recorded music industry, occupying an 80 percent market share by 1960 (Keightley 2004, p. 378). The core materiality of that core commodity and of recorded music commodities for the rest of the century - was plastic.

In accounting for the shift from shellac to plastic, in particular the polyvinyl chloride (PVC) from which LPs are made, most writers point to technological advances (e.g. Kolodin 1957). That is indeed one kind of explanation, as LPs were said to have 'very quickly assumed a position of general superiority as to quieter playing surface, frequency range, and clarity' (Read and Welch 1976, p. 324) while their 'hair-width' microgrooves were celebrated for their increased playback time (Gelatt 1977, pp. 290291). However, it is possible to suggest, with Osborne (2012, p. 67), that the 'downfall' of shellac was not strictly a matter of sound quality: 'despite the 'frying-bacon' sizzle of its surface noise', he says, 'shellac was a format capable of withstanding continued audio improvement' (cf. Myers 1946). Accounting for the downfall of shellac therefore requires 
a more complicated explanation than straightforward technological progress. Political ecology is an important part of that story.

The Second World War looms large here, as the Japanese occupation of key shellac-producing regions reduced supply in the west. While the Canadian and British governments instituted salvage campaigns that recycled tens of millions of 78s (Anon. 1942a; Osborne 2012, p. 67), the US War Production Board instituted rationing policies that shrank nonmilitary uses of shellac by 70 percent (Anon 1942b, 1942c, 1942d; cf. Chasins 1943). The scarcity of shellac caused prices to continue rising in the immediate postwar period, from a 'normal' $\$ 14$ per tonne to approximately $\$ 45$ per tonne (Myers 1946, p. 413). Unlike the shellac situation around the First World War, though, where demand offset inflation, the embargoes of World War II created a conjuncture in which the recording industry was impelled to consider other materials (Winner 1944).

They found what they were looking for in PVC, a synthetic polymer derived from a petrochemical called ethylene. Although PVC had been available since the 1930s, it was prohibitively expensive. Only in the midst and aftermath of the Second World War did PVC become a commercially viable material in the record industry. When the LP had firmly taken hold of the market in 1960, British record companies annually consumed 5 million kilograms of PVC (Scaping 1979, p. 136). With the LP's peak in Britain during the late 1970s, at nearly 130 million units, the amount of vinyl jumped to 22 million kilograms (5 percent of the country's total yearly PVC output). Extending this to the height of worldwide sales — 942 million units worldwide in 1978 — the LP weighed in at 160 million kilograms. 
In sourcing all that PVC, and in refining its suitability for sound reproduction, the record industry forged new partnerships with plastics and petrochemical industries. The largest single PVC producer in the UK at that time was British Petroleum (Scaping 1979, p. 136); the major US suppliers were the DuPont, Union Carbide and Dow Chemical corporations, as well as diversified automotive interests such as Goodrich, Goodyear and Tenneco (Anon 1949; Martin 1951, p. 78; Duston 1974, p. 3). Indeed, the LP was seen as 'a monument to the cooperation of the record industry with the plastic industry' (Isom 1977, p. 723; cf. Khanna 1977) and developments in one field were followed closely in the other. Music industry trade papers such as Billboard covered the invention of new plastic resins, while chemical engineering trade papers such as Plastics kept a watchful eye on the record industry's need for new materials. Both industries relied on petrochemicals and so variations in the oil market could directly affect their profit margins and production capacities. ${ }^{10}$ Such variations were tracked with interest in music journals such as Billboard (Kirsch 1973, Anon 1974, Kozak 1976, Traiman 1979). As part of a more general 'triumph' of plastic in the twentieth century (Bensaude-Vincent and Stengers 1996, p. 201; cf. Meikle 1995), this era of the recorded music commodity brought about a new system of relationships between the recording industry and chemical engineering and energy corporations. It also marks the moment when the recording industry's ecological centre of gravity shifted from the forests of the Southeast to the oil fields of the Middle East. ${ }^{11}$

Nowhere is the finality of the shift from shellac to plastic better illustrated than in a story told by the comedian Barry Humphries (1992, pp. 129-133), also known as Dame Edna. In the mid 1950s, Humphries took a job at EMI in Melbourne. After 
apprenticeships in 'push[ing] boxes of records around the warehouse' and 'wandering amongst the aisles of steel shelving', Humphries got his first big break: he was instructed to go down into the basement of EMI, to pick up a hammer and destroy the company's stock of discontinued $78 \mathrm{~s}$ - to shatter it, disc by disc, making way for microgrooves. What a waste! Surely these recordings should have been sold off to collectors, donated to museums and archives or, as Humphries himself protested, given 'to hospitals, to old people's homes'. But they weren't. While part of this has to do with copyright legislation (deletions cannot legally be sold or given away) it also says something about the temporal logic of the recorded music commodity.

Unpacking such temporal logics actually takes us back to the beginning of sound reproduction, where the new technology offered manifestly peculiar temporal possibilities. Indeed, says Sterne (2003, p. 287), 'If there was a defining figure in early accounts of sound recording, it was the possibility of preserving the voice beyond the death of the speaker'. But the possibility of preservation actually gave rise to a tension between permanence and ephemerality — a 'preservation paradox' — which has 'been a fundamental condition of recording throughout its history' (Sterne 2008, p. 59). In the words of media historian Daniel LeMahieu (1988, p. 88), writing about the rise of the gramophone in Britain, 'Recorded sound transcended time, and yet in another sense, this modern, technological form of permanence contributed to the transience of music'. He explains:

Until Edison made his discovery in 1877, no sound survived the moment of its passing. The gramophone allowed music to transcend the boundaries of time, 
thereby offering the performer a new promise of immortality. ... This hope for immortality on shellac often became lost, however, in the continual and often extraordinarily rapid turnover of records. . . Popular records became almost as transitory in the market-place as the ephemeral sound which they preserved... . Within a few generations, records produced by the thousands and millions became rare items. Many were lost altogether. The promise of immortality ... was often broken by the realities of commerce. (LeMahieu 1988, pp. 88-89)

These temporal dialectics gave rise to a 'collecting impulse' (Shuker 2010), which became increasingly pronounced with the rise of electrical recording and the standardisation of the 78. It was during the 1920s, for example, that American libraries started seriously collecting sound recordings (Almquist 1987, pp. 13-16). For individual listeners, this transition took on a particular meaning in relation to the recording's temporal logic: 'The eclipse of acoustical recording', says LeMahieu (1982, p. 379), 'accelerated the trend whereby old records were traded in, destroyed, or forgotten in favor of more current performances. By the late 1920 s . . the records of many opera singers from the earliest days of the gramophone became distressingly rare'.

One response to that distress came in the form of a new column in The Gramophone: 'Collector's Corner', which 'during the 1930s defined the art of collecting historic recordings' (ibid.). What's more, this Gramophone column emerged alongside related commentary in venues such as Melody Maker and Down Beat, as well as a new literature in collector guides and discographies (Shuker 2010, pp. 25-27). Such commentary existed in relation to both classical and popular repertoires, especially jazz 
(Millard 2005: 252), and the practice of collecting was guided not only by the logic of cultural preservation but also completism, discrimination and distinction (Shuker 2010, pp. 17-21).

Shellac records were thus collectible from early on; people felt attached to them, in terms of both the anxieties of heritage (cf. Maisonneuve 2001) and the pleasures of fandom (cf. Hennion 2007). Yet most of the artifacts of the 78 era have disappeared. Part of this has to do with the infamous fragility of shellac discs. But delicacy alone cannot explain why, apart from a minority population of antiquarians, $78 \mathrm{~s}$ were so readily trashed, so easily lost and so quickly forgotten. ${ }^{12}$

An important aspect of that explanation stems from shifts in home economics and care for the self, which had also been emerging since the 1920s. This was a conjuncture in which new forms of convenience and new ideologies of cleanliness shaped a new 'ethos of disposability: chewing gum, cigarette butts, razor blades, and paper products' (Strasser 1999, p. 173). As cultural commodities, recordings are of course subject to different logics than throwaway packaging and disposable razors (even if certain types of popular music have been scoffed at for their resemblance to bubblegum). Still, the apparent appetite for the supersession of shellac by plastic must be seen, not only as part of the preservation paradox that marks all recording, but as part of the particular culture of disposability and dispossession that was developing in the early twentieth century (cf. Lucas 2002).

Vinyl is also part of this moment, though the two formats have broadly different afterlives. They do not meet the same ends, physically or symbolically. Whereas the cultural and economic value of obsolete shellac bottomed out and met with destruction, 
Straw (1999-2000, p. 162) shows that undesirable vinyl records tend to circulate almost endlessly in secondary economies where, even though their value is exhausted, they accumulate in 'museums of failure' in which 'their bulk nevertheless functions almost monumentally'. In other words, shellac 78s seem predisposed to be disposed, while vinyl LPs seem prone to pile up.

One reason for this difference has to do with the way LPs were articulated to the seriousness of adult culture and the contradictory anti-commercialism of rock. As Keightley (2004, p. 386) argues, 'long play' refers not just to 'the extended duration of musical playback' but also 'the album's ongoing cultural and economic presence'. Indeed, in contrast to the ephemerality that characterised both its predecessor (the 78) and its contemporary (the 45), the LP possessed 'heightened symbolic capital' and was 'more and more perceived to occupy a cultural space similar to that of books' (ibid., p. 383). This is what Keightley refers to as 'the slower temporal logic of the LP'. While shellac and vinyl were subject to broadly similar forms of attachment, the slower temporal logic and particular accumulative tendency of the LP as a thing stem not only from its physical durability but from the meanings that accrued to it as a format. This is a curious irony, given the wider cultural history of plastic, throughout which the material has been much derided as a symbol of a cheap, artificial, throwaway society (Meikle 1995).

Nevertheless, the symbolic and temporal logics of the plastic LP shed light on its recent and widely reported revival, as well as and its longer-term (if belittled) survival.

Of course, some LPs do not survive. And despite the fact that the PVC in LPs may technically be recycled (Ríos 2011), it is generally not economically worthwhile to do so. As such, when truly exhausted LPs finally die, they will end up in incinerators and 
landfills - scenarios in which various toxins, including carcinogenic dioxins, will be released into the atmosphere and groundwater (Wittchen 2012). However, given their temporal and accumulative logics, for the moment it seems that the 'social death' (Gabrys 2011) of the LP will weigh more heavily on our shelves than the environment. ${ }^{13}$

\section{Data}

Anxieties about the material status of music have "wound their way through the long history of philosophical aesthetics' (Straw 2012, p. 229; cf. Bowman 1998). But such anxieties take on a distinctive shape in relation to sound reproduction, and they possess a distinctive urgency in relation to the popularisation of the MP3. Take for example the remarks of BBC presenter Michael Smith (2012), for whom the release of Beck's conspicuously old-fashioned Song Reader (2012), a book of sheet music, occasioned reflection on the fate of music in the digital age:

The story of music in my lifetime has been a trajectory wherefrom the precious totemic object [i.e. the LP] to a dematerialized data stream — an online cul-de-sac where the vast body of recorded music is a lukewarm corpse, to be picked over at the click of a mouse, rented from somewhere up there in the cloud for a tenner a month.

Smith argues lovingly that vinyl LPs 'condensed and stored [music's] spirit', implying that digital music is stripped of its aura and somehow, therefore, colder and deader than previous forms of sound reproduction. This is a familiar argument, and a problematic 
one. It is problematic because Smith misses the fact that similar critiques go back to the dawn of mechanical sound reproduction (historically speaking, the LP is less 'precious' than he realises; cf. Sousa 1906). He also misses the subtlety and ambiguity with which such questions have been treated elsewhere (conceptually speaking, the loss of aura is more ambiguous than he allows; cf. Benjamin 1968). Indeed, the rest of this article could be devoted to unpicking what Sterne (2006a, p. 338) would call the 'dubious metaphysics' of Smith's grievance. But such critiques are established. Instead, I want to focus on Smith's suggestion that music digitalised is music dematerialised.

Empirically, there is some truth to the equation of digitalisation and dematerialisation. While the MP3 itself is not immaterial (the scale of its materiality is invisible), MP3s do have less 'physical presence' than CDs (McCourt 2005, p. 249). ${ }^{14}$ As Jeremy Morris (2013, p. 2) puts it, 'Album art, jewel cases, and other packaging remnants have morphed into metadata, tags, software interfaces, and other less tactile forms'. For this reason, some environmental reports claim that digitalisation can reduce the 'material intensity' of music by as much as 80 percent, compared to CD-oriented physical retail and e-commerce scenarios (Türk et al. 2003, p. 34; Weber et al. 2010, p. 763). But Smith's rhetoric ignores, while the scientific research brackets, two central material components of listening to music as data: delivery infrastructure and accessory hardware. In terms of delivery infrastructure, downloading may indeed use fewer resources (no plastics) and generate less pollution (no physical shipping) than other formats - but only in specific circumstances. Most studies advancing arguments about the reduction of material intensity in online scenarios assume that MP3 listening is a matter of downloading an album once (from iTunes, say) and accessing it forevermore on a local 
hard drive. However, this form of listening exists alongside (and potentially in the shadow of) streaming and subscription services such as Rhapsody, Spotify and, now, iTunes Radio — not to mention the extremely high traffic in 'incidental' music streaming on sites such as YouTube (IFPI 2014). Such media channels mean that a large proportion of digital music's resource and energy quotients come from 'indirect sources' (Bottrill et al. 2008, p. 7). Though the material intensity of this delivery infrastructure is distant, it is nevertheless substantial (Morris 2008). Indeed, emerging scholarship calls attention to the 'aggregate material effects of discrete acts' — such as music downloading and streaming — 'that seem, to the online user, utterly virtual' (Carruth 2014, p. 358). In looking at those aggregate material effects, a different picture emerges. A single large server farm, for example, can consume thousands of megawatts of electricity (enough to power millions of homes). ${ }^{15}$ What's more, the number of server farms data centres is increasing, with their collective carbon footprint already similar in size to that of the airline industry and set to increase at least fivefold by 2020, thus raising what Sean Cubitt et al. call an 'emerging energy crisis of information' (2011, p. 156). Additionally, the underground and undersea cable networks that constitute the backbone of this infrastructure, and which transmit the vast majority of its data in the western world, can raise their own environmental concerns. This is the case both in terms of possible habitat disruption when the cables are buried underground and laid across the ocean floor, as well as the materials and practices required to make such cables — the demand for which is growing (Maxwell and Miller 2012, pp. 57-58; cf. Starosielksi 2012). ${ }^{16}$ Music is complicit in all these developments. It is for these reasons necessary that music scholars counter the 'big white fluffy' connotations of cloud computing by stressing 'the cold hard physicality of 
warehouses, servers, generators and climate control devices' (Morris 2011, p. 3). Such an understanding not only provides grounds for a critique of the commodity status of digital music; it also strikingly asserts the material intensity of digital music.

The question of how to access this network, this infrastructure, opens up another corrective to notions of digital dematerialisation. Hard drives, routers, laptops, data sticks, memory cards, MP3 players, smartphones, headphones — these devices are resolutely material and, in various configurations, absolutely essential to digital music listening. What's more, the amount of such accessory technologies is massive, and it is growing (Maguadda 2011, p. 19). Other researchers therefore suggest that any dematerialisation wrought by digital music delivery systems is offset by a larger overall throughput of digital devices (Hogg and Jackson 2009, p. 338; cf. Berkhout and Hertin 2004). Yet it is more common, as Smith's discussion of Beck indicates, to tune out hardware and speculate on the ostensibly supernatural qualities of the data.

The disembodied character of the MP3 gives rise to some particular ways of thinking about the relationship between permanence and ephemerality. Here is André Millard (2005, p. 405) for example:

Recordings once had a permanence that price, rarity, and beauty gave them, but nowadays they are invisible digital files winging their way through cyberspace easily duplicated and just as easily thrown away. Digital recordings . . . are disposable in a way that expensive discs of vinyl or shellac could never be. Once consumed they do not even have to be thrown away: a press of a button and they are erased or dumped into the computer's invisible wastebasket. 
Journalist Llewellyn Hinkes (2009) provides a snappier summary of this discourse in his article on 'The Transient, Digital Fetish': 'Old formats ooze historical significance', he says; 'new ones are deleted with a tap'.

With downloading and data streaming, there is indeed a sense in which the MP3 severs the connection between economic and physical decay that defines earlier formats. For, regardless of the value of a song or album, its conditions of im/possibility pull in two directions at once: availability seems assured in the cloud network, on the one hand, and deletion is always threatened by the fussiness and impermanence of digital storage, on the other. In Elodie Roy's (2013) words, digitalisation is at once 'a total, continuous archive' and 'a space of loss, degradation and ultimate erasure'. Sterne (2008, p. 64) puts this in historical perspective: 'If early recordings were destined to become lost recordings', he says, 'digital recordings move in the same direction, but they do so more quickly and more fitfully'. Ultimately, then, the future of digital music will be governed by a logic of the trace; it will be 'a future where most digital recordings will be lost, damaged, unplayable, or separated from their metadata, hopelessly swimming in a potentially infinite universe of meaning' (ibid., p. 65; cf. Roy 2014).

Apart from any potentially unique aspects of the dynamic of disposability and durability that animates the social life of the MP3 itself, and aside from the work of remembering and forgetting that defines digital music as a politics of the archive, the question of the recorded music commodity's temporal logic is also in a sense transposed onto accessory hardware. ${ }^{17}$ Of course, the recording industry has always been aligned with makers of accessory hardware, which is to say the consumer electronic goods 
industry (Frith 1987, Frith 1988, Frith 2001). Indeed, a more comprehensive political ecology of recorded music would have to account for a longer history of playback technologies such as gramophones, radios, home and personal stereos, as well as all their woods and wires, papers and plastics, tubes and transistors. Of most interest here, though, is the sense in which digitalisation intensifies the relationship between the recording and electrical goods industries. ${ }^{18}$ This intensification goes beyond standalone MP3 players, given the extent to which the global proliferation of gadgets such as smartphones and laptops has been bolstered by the ways such devices function as partly (but significantly) musical devices. Importantly, such listening devices instance a higher turnover rate than earlier ones. The accelerated temporal logic of contemporary electronics devices is rooted in an industrial-cultural conjuncture that demands constant software updates and which insists on newness. While these commodities are not quite 'made to be wasted', like plastic water bottles (Hawkins 2013), in terms of both technology and fashion they are built to obsolesce — born to die. Digital music thus contributes to another problem: electronic waste.

The Environmental Protection Agency (2011, p. 1) estimates that 438 million new electronics products were sold in the United States during 2009, with nearly 7 tonnes either in storage or 'ready for end-of-life management'. About 75 percent of those devices were disposed of, rather than recycled in some way. Quantitatively, music is only a small part of this much bigger problem. ${ }^{19}$ But the very fact of its contribution to the ewaste stream emphasises that digitalisation does not dematerialise the production or consumption of music. Rather, it changes the scale and character of music's materiality. Analogously, digitalisation neither extinguishes the emissions profile nor sublimates the 
scrap signature of the recording industry; it changes them in complex ways. Like earlier predictions about the paperless office, claims about the possibility of a weightless musical culture assume an untenable lightness of being.

Digital music's material intensity is additionally consequential in the postcolonial world. This is partly because the so-called Global South is seen 'a reservoir of First World hand-me-downs and sleepy-eyed memories of its earlier consumer items' (Taussig 1993, p. 232), thus serving as a dumping ground for 70-80 percent of the Global North's e-waste (Gabrys 2011, p. 129). But it is also because the centrality of mobile listening technologies is equally and perhaps more pronounced in the South than in the North. This is due to the fact that, in infrastructure-challenged parts of the world, internet penetration via underground and submarine networking cables lagged behind the availability of personal, mobile digital devices. In the North, by contrast, hardwired and PC-based internet access preceded that of mobile phones and memory cards. Regions in the Global South have thus constructed their own diverse uses and practices surrounding mobile communications technologies (e.g. Ling and Horst 2011), along with their own listening practices, their own logics of musical possession and dispossession — and, consequently, their own corresponding debris fields.

Take for example the ubiquity and significance of data sticks, memory cards, music download vendors and mobile phone listening in India (Deo and Duggl 2013; Rai 2013, Manuel 2014). Such developments, which represent a marked change from the earlier 'cassette culture' described by Peter Manuel (1993), are attributed to the 'increasing affordability of multimedia-enabled phones and voice/data plans and wider penetration of mobile coverage' and mean that 'the mobile phone has quickly become the 
most prevalent digital music device' (Kumar and Parikh 2013, p. 2863). The rise of the mobile phone and digital music — which may be considered part of India's 'pirate modernity' (Sundaram 2010) — is linked to an alarming rise in local e-waste generation (e.g. Borthakur and Sinha 2013). Nevertheless, the influx of e-waste from other countries may still represent the most significant challenge. The memory of one northeastern Indian recycler highlights the role of music in a longer history of e-waste: 'At first, we dealt with record players, radios, VCRs and black-and-white TVs. Later on, CD and DVD players followed. Finally, computers arrived, and we started business with e-waste' (Mohammed Moinuddin quoted in Gallagher 2014). In these ways, the political ecology of music in India has transitioned, over the course of a century, from tree branches to data sticks. Shifting listening practices and shifting musical formats are thus tied to shifting practices of dispossession and disposal. This is the often hidden topological connection between making and unmaking, at simultaneously global and local levels, which a political-ecological approach to recorded music seeks to uncover.

Similar issues arise in other places. In Kenya, for example, where the local record industry 'has been largely informal and undercapitalized since the multinational record companies pulled out of the country in the 1980s', the recent explosion of a music-based subsector of the telecommunications industry could mark a new beginning (Eisenberg 2012). Kenya's digital music listening practices and economies — like those of India and like those of increasingly numerous other African nations — take place primarily through mobile and handheld devices (IFPI 2014, Matinde 2014). In addition to streaming and downloading, there are significant markets in ringtones and ringback tones, a service by which subscribers can customize the sound heard by callers as they wait for someone to 
pick up. Regardless of the questionable long-term financial viability of such developments, due to licensing and piracy among other issues (Eisenberg 2012; cf. Gopinath 2013), the increasing centrality of personal electronics in the contemporary global listening formation makes it necessary to face the ways that m-commerce means ewaste. This is the dynamic that defines the political ecology of music at the outset of the twenty-first century.

\section{Conclusion}

The industrialisation and mass production of music have been seen primarily as ideological problems (e.g. Benjamin 1968, Adorno and Horkheimer 1972) while issues of life and death have been used productively as laboratories for cultural theory (e.g. Mowitt 1987, Auslander 2002, Stanyek and Piekut 2010). Political ecology invokes a complementary and literally grounded range of critical issues. It shows that, just as 'the modern process of consumption ... is as much about dispossession as possession' (Lucas 2002, p. 19), so is the anthropology of music as much about decomposition as composition. And whereas the phrase 'music industry' typically 'describes a complex network of rights-owners and licensed users, a continual flow of rights income which seems inexhaustible and sometimes, indeed, quite random' (Frith 2004, p. 176), the phrase can equally describe a complex network of materials-extraction and materialsprocessing, a continual flow of exhaustible resources and exhausted commodities, of patterns of accumulation and dispossession which have discernible and describable logics

— as well as measurable material consequences. 
In other words, while the political economy of music may follow a path of abstraction, from the solidity of manufacturing to the airiness of rights agreements (Frith and Marshall 2004), the same cannot be said of the political ecology of music. What sometimes seems like a story of progressive dematerialisation and eco-friendliness - an evolution from sticky resins and fuming factories to pristine data streams and unworldly cloud networks - might in fact be just the opposite. In terms of political ecology, the move to a data-based musical materiality could represent a step in the wrong direction: from the use of raw materials that are relatively renewable (shellac) and commodities which are readily recycled in secondary economies (LPs) to delivery infrastructures that weigh heavily on the environment (server farms) and musical commodities with short life expectancies (accessory electronics) and ambiguous afterlives (MP3s).

Although a lot more research would be needed to say for sure whether the metabolism of recorded music is speeding up or slowing down, and while the material intensity of recording is only one part of a larger set of problems, music is nevertheless mentioned quickly and frequently in environmental criticism as a phenomenon that symbolises the worst excesses of development, consumption and waste. In her excellent Social History of Trash, for example, Susan Strasser (1999, p. 5) points to the 'incessant proliferation of musical-reproduction formats' as an emblem of modern wanting and wasting (cf. Robbins 2012, pp. 1-3). This is where the methodology of political ecology benefits most from its partnership with the politics of ecomusicology: for if a greener musical culture is an imperative, one way to get there is by greening music studies. ${ }^{20}$ 


\section{Acknowledgments}

Thanks, first, to Tom Everrett; I wouldn't have come to this topic without him. For comments and conversation at various stages of the research, thanks also to Alyssa Beaton, Georgina Born, Vebhuti Duggl, Gabrielle Kielich, Vibodh Parthasarathi, Nick Prior, Elodie Roy, Jonathan Sterne and Paul Théberge. For inspiring this project in important ways, thanks to Georgie's Music and Digitization Research Group at the University of Oxford: Geoffrey Baker, Alexandrine Boudreault-Fournier, Aditi Deo, Andrew Eisenberg and Patrick Valiquet. I have presented parts of this research on a few occasions, and I'm very grateful for all the discussion in those contexts: thanks to the Department of Music at City University London, Stan Hawkins and the Department of Musicology at the University of Oslo, the 'Musical Materialities in the Digital Age' conference at the University of Sussex, the 'On Collecting: Music, Materiality and Ownership' conference at the National Museum of Scotland, and the American Musicological Society's annual conference in Milwaukee. 


\section{Endnotes}

${ }^{1}$ This essay focuses on recordings themselves, on the material forms that contain musical information. It would be possible (and is desirable) to extend the analysis to record packaging, distribution and playback technologies. In the interest of space, these issues are largely bracketed here. I address such topics more fully in the monograph project that this article introduces. A few more caveats will help to define the horizon of this article. First and foremost, perhaps, it is worth noting that the conception of political ecology developed here does not necessarily distinguish between music genres. My interest is in the whole of 'record culture'. Nevertheless, it is true that popular music recordings make up the bulk of total record sales. As such, while political ecology is not an issue exclusive to popular music or popular music studies, the world of popular music seems to shoulder a special responsibility in relation to the political ecology of music (cf. Ingram 2007). In quantifying this material intensity, this article provides numerous annual weights and measurements for recorded musical materials. All such figures represent my best estimates at this stage of my research; in cases where the amounts are controversial or uncertain, I provide footnotes. Additionally, I have encountered these figures in various currencies (especially British pounds and American dollars) and various weights (pounds, short tons, metric tonnes). While I have retained the original currencies, I have presented all weight measurements in kilograms. Basic conversion and rounding rules apply.

Finally, I should also acknowledge that the United States and the United Kingdom tend to serve as the geographic perspectives from which I build my analysis. The possibilities of political ecology, though, are of course global and multiperspectival. 
${ }^{2}$ This is not to say that political ecology is disinterested in the aesthetic realm. Rather, as I imply in several parts of this article, a political-ecological approach might help us see aesthetically consequential musical developments in places where conventional analysis might least expect them: in bugs, rocks and oil. Although beyond the scope of this essay, there are resonances worth exploring in Benjamin Piekut's very rich conception of 'historical ecologies'. An historical ecology, for Piekut (2014, p. 212), is 'a web of relations, an amalgamation of organic and inorganic, or biological and technological, elements that are interconnecting and mutually affecting'. The point of this very broad understanding of the musical world, as with mine, is to discover 'new stories about music and its many allies' so that, perhaps, “'the music itself' returns with a difference' (Piekut 2014, pp. 212, 213).

${ }^{3}$ For a valuable contribution to media ecology that is consistent with this project's emphasis on new materialism, but which is not concerned with manufacture and disposal, see Fuller (2005).

${ }^{4}$ Shapes ranged from cylindrical tubes to flat round discs, with diameters from under 15 centimetres ( 5 inches) to 50 centimetres ( 20 inches). Speeds generally ranged from 60 to $130 \mathrm{rpm}$. In addition to Condensite, several of Edison's material alternatives to shellac discs (e.g. Blue Amberol) involved the use of a weak acid called phenol — which, because of its use in synthesizing aspirin, formed a chemical bond between the music industry and pharmaceutical companies such as Bayer (cf. Jeffreys 2008, p. 112). On the story of Condensite as a forerunner of Bakelite, see Bijker (1995). For excellent 
discussions of chemical technology during Edison's day, see Vanderbilt (1971) and Burt (1977).

${ }^{5}$ Osborne (2012, p. 18) explains: 'Following the introduction of electric recording Victor's speed of $78.26 \mathrm{rpm}$ was adopted as the industry standard in America and the Gramophone Company's speed of $77.92 \mathrm{rpm}$ was adopted in Britain. The reason for the difference is that early constant speed motors in America (with its mains frequency of 60 $\mathrm{Hz}$ ) ran at 3,600 rpm (using a gearing of 46:1 leaves the $78.26 \mathrm{rpm}$ figure) whereas in Britain the mains frequency is $50 \mathrm{~Hz}$ (therefore with he same gearing the standard speed dropped to $77.92 \mathrm{rpm})^{\prime}$.

${ }^{6}$ Swadeshi International (2011) puts the peak annual yield at approximately 40 million kilograms. Berenbaum (1993, p. 27) provides the figure that between 1921 and 1928 in Europe, 16 million kilograms of shellac were used to press 260 million records. Gronow (1983, pp. 63, 66) indicates that, before the Stock Market Crash of 1929, and again with the recovery of the industry approaching 1950, global annual record sales could have met or exceeded the 260 million mark. Thus my estimate that, in 1940, record companies could have purchased about half of India's yearly shellac gross. Some American sources offer figures for global shellac production that equate to about 20 million kilograms (Anon 1942b, Anon 1942c), while others say that the US alone was importing roughly that same amount (Anon 1942d, Vanderbilt 1971). In the first decade of the twentieth century, Talking Machine News put the figure lower, at roughly 13 million kilograms, 
while still noting that nearly half that amount went to the US and that much of it went into phonograph records (Parthasarathi 2005, p. 29).

${ }^{7}$ Estimates on the number of beetles required to produce a kilogram of shellac range from the thousands to the millions (Anon 1913; Winner 1944, p. 56; Berenbaum 1993, p. 27; Freinkel 2011, p. 22).

${ }^{8}$ The cultivation and exportation of shellac were governed by the British Empire through this period of Indian history, which invites a postcolonial critique that is beyond the scope of the present investigation but which I take up in the larger project that this essay introduces. See also the excellent work of Vibodh Parthasarathi $(2005,2007)$.

${ }^{9}$ Putting the overall production of shellac discs in the billions is an extrapolation from Pekka Gronow's (1983) work, though it should be noted that production figures and sales records are difficult in general and particularly patchy before the First World War. Indeed, recording industry statistics are generally problematic and should be approached with caution (cf. Harker 1997).

10 There is actually a more complicated set of issues here. Some of the PVC in records was already recycled, for example, while some chemical companies used coal and natural gas in the production of their feedstock chemicals, especially in the wake of the 1973 oil crisis. Further discussion of these complexities is beyond the scope of this essay. 
${ }^{11}$ The political ecologies of the other two main music formats of the record industry's plastic era - cassettes and CDs — are in some ways variations on themes established in the LP era. For this reason, due to space limitations I have chosen to bracket them in this article. Of course, the cassette is an important (even underestimated) format (cf. Laing 1990, Manuel 1993). Since 1973, the standard substrate of cassette tape has been polyester terephthalate (PET). In terms of PET, at the height of the cassette format in 1988 (1.4 billion units) the recording industry produced a literally astronomical amount of tape per year: about 150 million kilometres of it — enough to stretch from Earth to the Sun. And, like the LPs, the cassette is hydrocarbon based (ethylene). The CD is made from a different plastic: polycarbonate. In 1996, when CD sales had overtaken the cassette and peaked at 2 billion units worldwide, the recording industry devoured 170 million kilograms of plastics in the form of polycarbonate discs and polystyrene cases (Türk et al. 2003, p. 16). As with LPs and cassettes, this activity necessitated close working relationships between the recording industry and companies such as $3 \mathrm{M}$, Bayer, Dow Plastics, DuPont, GE, and various international polymer suppliers (e.g. Traiman 1995, Clark-Mead 1997, Block 1998).

${ }^{12}$ See Shuker (2010, pp. 27ff) on contemporary 78 collectors.

${ }^{13}$ Today, too, as new CD sales plummet and physical CD collections are disowned, the question shifts from manufacture to afterlife. Of the billions of compact discs produced since the 1980s, the CD Recycling Center of America estimates that thousands of kilograms become obsolete each month. One online marketplace guesses that over a 
million tonnes of CDs are 'collecting dust in people's homes' (Witkin 2011; cf Türk et al. 2003). As with LPs, despite the fact that CDs are technically recyclable, most of them seem destined to end up in the waste stream. In the present moment, though, we witness an anomaly in the CD's logics of temporality and accumulation. The decline of shellac was marked by disappearance. The decline of vinyl was marked by particular modes of attachment and monumentality that lent it longevity. By contrast, the decline of the $\mathrm{CD}$ is paradoxically 'signaled in its very ubiquitousness' (Straw 2009, p. 82). The CD seems to have reached a critical mass where its ubiquity threatens its implosion. In other words, if the 78 disappeared quickly across a kind of cultural event horizon, and if the LP has been subject to a kind of gravitational time dilation, it is possible to argue that the $\mathrm{CD}$ is going supernova.

${ }^{14}$ For details of the materiality of software formats, see Sterne (2012, pp. 6-7, 194ff) and Kirschenbaum (2008).

${ }^{15}$ Server farms and data centres are of course not monolithic technologies. See Dourish (2014) on the particularities of database technology.

${ }^{16}$ For an entertaining account of the material geography of the internet writ large, see Blum (2012).

${ }^{17}$ Morris (2010, p. 32) argues similarly that the 'fetish logic' of the digital music commodity is 'displaced to other aspects of the commodity'. 
${ }^{18}$ As this and the next few sentences suggest, I would argue that the dynamics of digital electronics devices in contemporary musical culture can be seen as extensions of patterns discussed by Paul Théberge in relation to the arrival of digital instruments. Théberge (1997, pp. 243, 245) notes both 'the degree to which technological innovation in the [musical] field has become dependent upon ... technologies originating within the computer industry' and 'a new temporal dimension' in purchasing habits: 'the increasing pace of technical innovations within the microprocessor-based musical instrument industry since the 1980s suggests that an investment in high technology will likely become obsolete within one or two brief product cycles'. See also Slade (2006) on the role of radio in establishing the ideas of planned obsolescence and 'death dating' in the consumer electronics industry.

19 The contributions of smaller polluters, down to the level of the individual consumer, may seem insignificant — an ineffective starting point for change. 'But', say Maxwell and Miller (2012, p. 30), 'we should note the premise of Greenpeace's strategy: it assumes the futility of consumer decision making as a basis for massive change'.

${ }^{20}$ I am paraphrasing here from Maxwell and Miller (2012, p. 21). 


\section{Bibliography}

Acland, C. ed (2007) Residual Media, Minneapolis, University of Minnesota Press.

Acland, C. (2014) 'Dirt Research for Media Industries', Media Industries Journal, vol. 1, no. 1 , pp. 6-10.

Adorno, T. \& Horkheimer, M. (1972) Dialectic of Enlightenment, New York, Herder \& Herder.

Allen, A., et al. (2011) 'Colloquy on Ecomusicology', Journal of the American Musicological Society, vol. 64, no. 2, pp. 391-424.

Allen, A. (2012) 'Stradivari’s Violins and the Musical Trees of the Paneveggio', in Invaluable trees: Cultures of Nature, 1660-1830, ed L. Auricchio et al., Oxford, Oxford University Press.

Allen, A. (2013) 'Ecomusicology', in The Grove Dictionary of American Music, New York, Oxford University Press.

Almquist, S. (1987) 'Sound Recordings and the Library', Occasional Papers (179): Graduate School of Library and Information Sciences, University of Illinois. 
Anon (1913) The Story of Shellac, New York, William Zinsser \& Co.

Anon (1942a) 'Old Records Yield Valuable Shellac'. Hamilton Spectator (18 August).

Anon (1942b) 'Diskers Ready New Plans', Billboard, vol. 54, no. 17, pp. 68, 74.

Anon (1942c) 'Diskers Eye WPB Action', Billboard, vol. 54, no. 26, p. 70.

Anon (1942d) 'Financial Journal Features News of Shellac Situation and Prices', Billboard, vol. 54, no. 44, pp. 62, 68.

Anon (1949) 'Plastics in the Making of Phonograph Records', Plastics, vol. 9, no. 2, p. 5.

Anon (1974) 'Tape Industry Shortage Eases; Benefits Gained', Billboard (15 June), pp.

3, CES-12-13.

Appadurai, A. ed (1986) The Social Life of Things: Commodities in Cultural Perspective, Cambridge, Cambridge University Press.

Appadurai, A. (1990) 'Disjuncture and Difference in the Global Cultural Economy', Public Culture, vol. 2, no. 2, pp. 1-24.

Appadurai, A. (1996) Modernity at Large: Cultural Dimensions of Globalization, 
Minneapolis, University of Minnesota Press.

Appadurai, A. (2006) 'The Thing Itself', Public Culture, vol. 18, no. 1, pp. 15-21.

Auslander, P. (2002) Liveness: Performance in a Mediatized Culture, New York, Routledge.

Barad, K. (2003) 'Posthumanist Performativity: Toward an Understanding of How Matter Comes to Matter', Signs, vol. 28, no. 3, pp. 801-831.

Barry, A. (2005) 'Pharmaceutical Matters: The Invention of Informed Materials'. Theory, Culture and Society, vol. 22, no. 1, pp. 51-69.

Barry, A. (2013) Material Politics: Disputes Along the Pipeline, Oxford, Wiley Blackwell.

Behr, A. (2015) 'Cultural Policy and Creative Industries', in The Routledge Reader on the Sociology of Music, ed. J. Shepherd and K. Devine, New York, Routledge.

Benjamin, W. (1968) 'The Work of Art in the Age of Mechanical Reproduction', in Illuminations, New York, Harcourt, Brace \& World.

Bennett, T. et al. (2009) Culture, Class, Distinction, Abingdon, Routledge. 
Bennett, J. (2010) Vibrant Matter: A Political Ecology of Things, Durham, Duke University Press.

Bensaude-Vincent, B. \& Stengers, I. (1996) A History of Chemistry, Cambridge, Harvard University Press.

Berenbaum, M. (1993) Ninety-Nine More Maggots, Mites and Munchers, Champaign, University of Illinois Press.

Berkhout, F. \& Hertin, J. (2004) 'De-Materialising and Re-Materialising: Digital Technologies and the Environment,' Futures, vol. 36, no. 8, pp. 903-920

Bijker, W. (1995) Of Bicycles, Bakelites and Bulbs: Toward a Theory of Sociotechnical Change, Cambridge, MIT Press.

Block, D. G. (1998) 'The Raw-Material World: Polycarbonate Supply Barely Meets Demand', Billboard (15 August), pp. 60, 62, 64.

Blum, A. (2012) Tubes: Behind the Scenes at the Internet, London, Penguin.

Born, G. (2005) ‘On Musical Mediation: Ontology, Technology and Creativity’, Twentieth-Century Music, vol. 2, no. 1, pp. 7-36. 
Born, G. (2010) 'The Social and the Aesthetic: For a Post-Bourdieuian Theory of Cultural Production', Cultural Sociology, vol. 4, no. 2, pp. 171-208.

Born, G. (2012) 'Music and the Social', in The Cultural Study of Music: A Critical Introduction, ed M. Clayton et al., New York, Routledge.

Borthakur, A. and K. Sinha (2013) 'Generation of Electronic Waste in India: Current Scenario, Dilemmas and Stakeholders', African Journal of Environmental Science and Technology, vol. 7, no. 9, pp. 899-910.

Borwick, J. (2003) '78', in The Continuum Encyclopedia of Popular Music of the World, ed. John Shepherd et al., New York, Continuum.

Borwick, J. (2003) 'Shellac', in The Continuum Encyclopedia of Popular Music of the World, ed. John Shepherd et al., New York, Continuum.

Borwick, J. \& Laing, D. (2003) 'Compact Disc', in The Continuum Encyclopedia of Popular Music of the World, ed. John Shepherd et al., New York, Continuum.

Bottrill, C. et al. (2008) First Step: UK Music Industry Greenhouse Gas Emissions for 2007, Oxford, Julie's Bicycle. 
Bourdieu, P. (1984) Distinction: A Social Critique of the Judgement of Taste, Cambridge, MA, Harvard University Press.

Bowman, W. (1998) Philosophical Perspectives on Music, Oxford, Oxford University Press.

Brown, B. (2001) 'Thing Theory', Critical Inquiry, vol. 28, no. 1, pp. 1-22.

Bull, M. (2007) Sound Moves: iPod Culture and Urban Experience, London, Routledge.

Burt, L. (1977) 'Chemical Technology in the Edison Recording Industry', Journal of the Audio Engineering Society, vol. 25, no. 10-11, pp. 712-717.

Carruth, A. (2014) 'The Digital Cloud and the Micropolitics of Energy', Public Culture, vol. 26, no. 2, pp. 339-364.

Chakrabarty, D. (2009) 'The Climate of History: Four Theses', Critical Inquiry, vol. 35, pp. 197-222.

Chasins, G. (1943) ‘Scrap Fights: Two Ways’, Billboard 1943 Music Year Book, New York, Billboard.

Chattopadhyay, S. (2011) Introduction to Lac and Lac Culture, Kanke, Birsa Agricultural 
University.

Clark-Meads, J. (1997) ‘Polymer Suppliers Are Called On To Help Curb Piracy’, Billboard (27 Sept), pp. 1, 119.

Clarke, E. (2005) Ways of Listening: An Ecological Approach to the Perception of Musical Meaning, Oxford, Oxford University Press.

Cloonan, M. (2007) Popular Music and the State in the UK: Culture, Trade or Industry? Aldershot, Ashgate.

Coole, D. \& Frost, S. eds (2010) New Materialisms: Ontology, Agency and Politics, Durham, Duke University Press.

Crutzen, P. (2002) 'Geology of Mankind: The Anthropocene', Nature, vol. 415, p. 23.

Cubitt, S. et al. (2011) 'Does Cloud Computing Have a Silver Lining?' Media, Culture and Society, vol. 33, no. 1, pp. 149-158.

Curry, P. (2008) 'Nature Post-Nature’, New Formations, vol. 26, pp. 51-64.

DeNora, T. (2000) Music and Everyday Life, Cambridge, Cambridge University Press. 
DeNora, T. (2011) 'Practical Consciousness and Social Relation in MusEcological Perspective', in Music and Consciousness: Philosophical, Psychological and Cultural Perspectives, eds D. Clarke and E. Clarke, Oxford, Oxford University Press.

Deo, A. \& Duggl, V. (2013) 'Buying Music in a Vegetable Market: Circulation and Consumption of Digital Music Among Non-Elite Indians', presented at Music, Digitization, Mediation Conference, University of Oxford, July.

Dolphijn, R \& van der Tuin, I. (2012) New Materialism: Interviews and Cartographies, Ann Arbor, Open Humanities Press.

Dourish, P. (2014) 'NoSQL: The Shifting Materialities of Database Technology', Computational Culture 4, online.

Duston, A. (1974) 'PVC Ad Brings Bootleg Offers Asking 3 Times Regular Price', Billboard (11 May), p. 3.

Echard, W. (2011) 'Psychedelia, Musical Semiotics, and Environmental Unconscious', Green Letters, vol. 15, no. 1, pp. 61-75.

Eisenberg, A. (2012) 'M-Commerce and the (Re)Making of the Music Industry in Kenya', presented at the Association of Social Anthropologists Meeting, Jawaharlal Nehru University, April. 
Eisenberg, E. (2005) The Recording Angel, New Haven, Yale University Press.

Environmental Protection Agency (2011) Electronics Waste Management in the United States through 2009: Executive Summary, Washington, EPA.

Environmental Protection Agency (2012) Climate Change Indicators in the United States, 2012, 2nd ed, Washington, EPA.

Freinkel, S. (2011) Plastic: A Toxic Love Story, New York, Houghton Mifflin Harcort.

Frith, S. (1987) 'The Making of the British Record Industry, 1920-64', in Impacts and Influences: Essays on Media Power in the Twentieth Century, ed J. Curran et al., London, Methuen.

Frith, S. (1988) 'The Industrialization of Music', in Music for Pleasure, New York, Routledge.

Frith, S. (2001) 'The Popular Music Industry', in The Cambridge Companion to Pop and Rock, ed S. Frith et al., Cambridge, Cambridge University Press.

Frith, S. (2004) 'Music and the Media', in Music and Copyright, ed S. Frith and L. Marshall, Edinburgh, Edinburgh University Press. 
Frith, S. (2012) 'The Sociology of Music in Britain', in Vingt-cinq ans de sociologie de la musique en France (Tome 1), ed E. Brandl et al., pp. 63-69, Paris: L'Harmattan.

Frith, S. \& Marshall, L. eds (2004) Music and Copyright, Edinburgh, Edinburgh University Press.

Fuller, M. (2005) Media Ecologies: Materialist Energies in Art and Technoculture, Cambridge, MIT Press.

Gabrys, J. (2011) Digital Rubbish: A Natural History of Electronics, Ann Arbor, University of Michigan Press.

Gallagher, S. (2014) 'India: The Rising Tide of E-Waste', Pulitzer Center on Crisis Reporting, < http://pulitzercenter.org/reporting/asia-india-electronic-waste-toxicenvironment>

Gaonkar, D. \& Povinelli, E. (2003) 'Technologies of Public Forms: Circulation, Transfiguration, Recognition', Public Culture, vol. 15, no. 3, pp. 385-397.

Gelatt, R. (1977) The Fabulous Phonograph, London, Cassell.

Gilbert, J. (2004) 'Signifying Nothing: Culture, Discourse and the Sociality of Affect', 
Culture Machine, vol. 6, online.

Glotfelty, C. Fromm, H. eds (1996) The Ecocriticism Reader: Landmarks in Literary Ecology, Athens, University of Georgia Press.

Gopinath, S. (2013) The Ringtone Dialectic: Economy and Cultural Form, Cambridge, MIT Press.

Gregson, N. \& Crang, M. (2010) 'Materiality and Waste: Inorganic Vitality in a Networked World', Environment and Planning A, vol. 42, pp. 1026-1032.

Grimley, D. (2006) Grieg: Music, Landscape and Norwegian Identity, Woodbridge, Boydell.

Gronow, P. (1983) 'The Record Industry: The Growth of a Mass Medium', Popular Music, vol. 3, pp. 53-75.

Guy, N. (2009) 'Flowing Down Taiwan’s Tamsui River: Towards an Ecomusicology of the Environmental Imagination', Ethnomusicology, vol. 53, no. 2, pp. 218-249.

Harker, D. (1997) 'The Wonderful World of IFPI: Music Industry Rhetoric, the Critics and the Classical Marxist Critique', Popular Music, vol. 16, no. 1, pp. 45-79. 
Hawkins, G. (2006) The Ethics of Waste: How We Relate to Rubbish, Lanham, Rowman \& Littlefield.

Hawkins, G. (2013) 'Made to be Wasted: PET and Topologies of Disposal', in Accumulation: The Material Politics of Plastic, ed J. Gabrys et al., London, Routledge.

Hayward, T. (1994) 'The Meaning of Political Ecology', Radical Philosophy, vol. 66, pp. $11-20$.

Hennion, A. (2007) 'Those Things That Hold Us Together: Taste and Sociology', Cultural Sociology, vol. 1, no. 1, pp. 97-114.

Hetherington, K. (2004) 'Secondhandedness: Consumption, Disposal and Absent Presence', Environment and Planning D, vol. 22, pp. 157-173.

Hinkes, L. (2009) 'The Transient, Digital Fetish', The Morning News (7 May), online.

Hogg, N. \& Jackson, T. (2009) 'Digital Media and Dematerialization: An Exploration of the Potential for Reduced Material Intensity in Music Delivery,' Journal of Industrial Ecology, vol. 13, no. 1, pp. 127-146.

Humphries, B. (1992) More Please, London, Viking. 
Hung, M. \& Morencos, E., eds (1990) World Recording Sales, 1969-1990: A Statistical History of the World Recording Industry, London, International Federation of the Phonographic Industry.

IFPI (2014) Digital Music Report, London, International Federation of the Phonographic Industry.

Ingold, T. (2007) ‘Materials Against Materiality’, Archaeological Dialogues, vol. 14, no. 1, pp. 1-16.

Ingold, T. (2012) 'Toward an Ecology of Materials', Annual Review of Anthropology, vol. 41, pp. 427-442.

Ingram, D. (2007) 'For Free? Theorising Consumption, Commerce, and the Environmental Costs of Artistic Production', Green Letters, vol. 8, no. 1, pp. 13-22.

Ingram, D. (2010) The Jukebox in the Garden: Ecocriticism and American Popular Music Since 1960, Amsterdam, Rodopi.

Isom, R. W. (1977) 'Evolution of the Disc Talking Machine', Journal of the Audio Engineering Society, vol. 25 no. 10-11, pp. 718-723.

Jeffreys, D. (2008) Aspirin: The Remarkable Story of a Wonder Drug, New York, 
Bloomsbury.

Johnson, B. (2008) “"Quick and Dirty”: Sonic Mediations and Affect', in Sonic Mediations: Body, Sound, Technology, ed C. Birdsall and A. Enns, Newcastle, Cambridge Scholars Publishing.

Jones, P. (1977) 'The Record Industry in Europe', Journal of the Audio Engineering Society, vol. 25, no. 10-11, pp. 789-794.

Jones, S. (2002) 'Music that Moves: Popular Muisc, Distribution and Network Technologies', Cultural Studies, vol. 16, no. 2, pp. 213-232.

Kassabian, A. (2004) 'Would You Like Some World Music with your Latte? Starbucks, Putumayo and Distributed Tourism', Twentieth-Century Music, vol. 1, no. 2, pp. 209223.

Keightley, K. (2004) 'Long Play: Adult-Oriented Popular Music and the Temporal Logics of the Post-War Sound Recording Industry in the USA', Media, Culture \& Society, vol. 26, no. 3, pp. 375-391.

Keightley, K. (2011) 'Un Voyage via Barquinho: Global Circulation, Musical Hybridization and Adult Modernity, 1961-69,' in Migrating Music, ed J. Toynbee and B. Dueck, Abingdon, Routledge. 
Kenney, W.H. (1999) Recorded Music and American Life: The Phonograph and Popular Memory, 1890-1945, Oxford, Oxford University Press.

Khanna, S.H. (1977) 'Vinyl Compound for the Phonographic Industry, Journal of the Audio Engineering Society, vol. 25 no. 10-11, pp. 724-728.

Kirsch, B. (1973) 'Industry Tackles Plastics Shortage', Billboard (6 October), pp. 1, 12.

Kirschenbaum, M. (2008) Mechanisms: New Media and the Forensic Imagination, Cambridge, MIT Press.

Kittler, F. 1999. Gramophone, Film, Typewriter, Stanford, Stanford University Press.

Kolodin, I. (1957) 'The Vinyl Decade', The Saturday Review (28 September), pp. 41, 43.

Kopytoff, I. (1986) 'The Cultural Biography of Things: Commoditization as Process', in The Social Life of Things: Commodities in Cultural Perspective, ed A. Appadurai, Cambridge, Cambridge University Press.

Kozak, R. (1976) 'If Oil Prices Ascend, Expect a PVC Jump', Billboard (27 November), pp. $1,73,90$. 
Kumar, N. and T. Parikh (2013) 'Mobiles, Music and Materiality', Computer-Human Interaction (27 April - 02 May), pp. 2863-2872.

Laing, D. (1990). 'Record Sales in the 1980s', Popular Music, vol. 9, no. 2, pp. 235-236.

Laing, D. (2003) 'Record Industry', in The Continuum Encyclopedia of Popular Music of the World, ed J. Shepherd et al., New York, Continuum.

Latour, B. (1998) 'To Modernize or to Ecologize? That's the Question', in Remaking Reality: Nature at the Millennium, ed B. Braun and N. Castree, New York, Routledge.

Latour, B. (2005) Reassembling the Social: An Introduction to Actor-Network-Theory, Oxford, Oxford University Press.

LeMahieu, D. (1982) 'The Gramophone: Recorded Music and the Cultivated Mind Between the Wars', Technology and Culture, vol. 23, no. 3, pp. 372-391.

LeMahieu, D. (1988) A Culture For Democracy: Mass Communication and the Cultivated Mind in Britain Between the Wars, Oxford, Clarendon.

Leonard, M. (2007) 'Constructing Histories through Material Culture: Popular Music, Museums and Collecting', Popular Music History, vol. 2, no. 2, pp. 147-167. 
Lepawsky, J. \& Mather, C. (2011) 'From Beginnings and Endings to Boundaries and Edges: Rethinking Circulation and Exchange through Electronic Waste', Area, vol. 43, no. 3, pp. 242-249.

Ling, R. and H. Horst (2011) 'Mobile Communication in the Global South', New Media and Society, vol. 13, no. 3, pp. 363-374.

Lucas, G. (2002) 'Disposability and Dispossession in the Twentieth Century', Journal of Material Culture, vol. 7, no. 1, pp. 5-22.

Lum, C. M. K., ed (2006) Perspectives on Culture, Technology and Communication: The Media Ecology Tradition, Cresskill, Hampton Press.

Lury, C, et al. (2012) 'Topologies of Culture', Theory, Culture and Society, vol. 29, no. 4-5, pp. 3-342.

Magoun, A. (2000) 'Shaping the Sound of Music: The Evolution of the Phonograph Record, 1877-1950', PhD thesis, University of Maryland, USA.

Maguadda, P. (2011) 'When Materiality “Bites Back”: Digital Music Consumption Practices in the Age of Dematerialization', Journal of Consumer Culture, vol. 11, no. 1, pp. 15-36. 
Maisonneuve, S. (2001) 'Between History and Commodity: The Production of a Musical Patrimony through the Record in the 1920-1930s', Poetics, vol. 29, no. 2, pp. 89-108.

Manuel, P. (1993) Cassette Culture: Popular Music and Technology in North India, Chicago, University of Chicago Press.

Manuel, P. (2014) 'The Regional North Indian Popular Music Industry in 2014: From Cassette Culture to Cyberculture', Popular Music, vol. 33, no. 3, pp. 389-412.

Marshall, L, ed (2013) The International Recording Industries, Abingdon, Routledge.

Martin, J. (1951) '51 Record Outlook For Ops Brightens', Billboard (17 March), p. 78.

Martland, P. (2013) Recording History: The British Record Industry, 1888-1931, Plymouth, Scarecrow.

Marvin, C. (1988) When Old Technologies Were New, Oxford, Oxford University Press.

Matinde, V. (2014) ‘Can Mobile Digital Music Help African Musicians?’ IDG Connect (12 June), <http://www.idgconnect.com/abstract/8384/can-mobile-digital-music-helpafrican-musicians> 
Maxwell, R. \& Miller, T. (2012) Greening the Media, Oxford, Oxford University Press.

McCourt, T. (2005) 'Collecting Music in the Digital Realm', Popular Music and Society, vol. 28, no. 2, pp. 249-252.

McClure, S. (1999) ‘Violence Doesn’t Faze Piracy Fighters’, Billboard (4 December), pp. 110, 114.

Meikle, J. (1995) American Plastic: A Cultural History, New Brunswick, Rutgers University Press.

Mellers, W. (2001) Singing in the Wilderness: Music and Ecology in the Twentieth Century, Chicago, University of Illinois Press.

Miège, B. (1979) 'The Cultural Commodity', Media, Culture and Society, vol. 1, pp. $297-311$.

Millard, A. (2005) America on Record: A History of Recorded Sound, Cambridge, Cambridge University Press.

Miller, D., ed (2005) Materiality, Durham, Duke University Press.

Morris, J. A. (2008) 'The Energy Nightmare of Web Server Farms', 
Synthesis/Regeneration, vol. 45, online.

Morris, J. (2010) ‘Understanding the Digital Music Commodity’, PhD thesis, McGill University, Canada.

Morris, J. (2011) 'Sounds in the Cloud: Cloud Computing and the Digital Music Commodity', First Monday, vol. 16, no. 5, pp. 1-12.

Morris, J. (2013) “"The Person Behind the Music We Adore”: Artists, Profiles, and the Circulation of Music', Wi: Journal of Mobile Media, vol. 7, no. 1, pp. 1-9.

Morton, T. (2007) Ecology without Nature: Rethinking Environmental Aesthetics, Cambridge, Harvard University Press.

Mowitt, J. (1987) 'The Sound of Music in the Era of Its Electronic Reproducibility', in Music and Society: The Politics of Composition, Performance and Reception, ed R. Leppert and S. McClary, Cambridge, Cambridge University Press.

Murphy, R. (1994) Rationality and Nature: A Sociological Inquiry into a Changing Relationship, Oxford, Westview Press.

Myers, K. (1946) 'Current Report on the Record Industry’, Notes, vol. 3, no. 4, pp. 411421. 
Novak, D. (2013) Japanoise: Music on the Edge of Circulation, Durham, Duke University Press.

Ochoa, A. M. \& Botero, C. (2009) 'Notes on Practices of Musical Exchange in Columbia', Popular Communication, vol. 7. pp. 158-168.

Osborne, R. (2012) Vinyl: A History of the Analogue Record, Farnham, Ashgate.

Parks, L. and N. Starosielski (forthcoming 2015) Signal Traffic: Critical Studies of Media Infrastructures, Champaign, University of Illinois Press.

Parikka, J. (2014) The Anthrobscene, Minneapolis, University of Minnesota Press.

Parthasarathi, V. (2005) 'Construing a "New Media” Market: Merchandising the Talking Machine, c1900-1913', in Media and Mediation, ed. B. Bel et al., Sage, New Delhi.

Parthasarathi, V. (2007) 'Not Just Mad Englishmen and a Dog: The Colonial Tuning of “Music on Record”, 1900-1908', Working Paper No.02/2008, Jamia Millia Islamia, New Delhi (July). 
Pedelty, M. (2012) Ecomusicology: Rock, Folk and the Environment, Philadelphia, Temple University Press.

Pels, D. et al. (2002) 'The Status of the Object: Performances, Mediations, and Techniques', Theory, Culture and Society, vol. 19, no. 5-6, pp. 1-21.

Peterson, R. (1992) 'Understanding Audience Segmentation: From Elite and Mass to Omnivore and Univore', Poetics, vol. 21, no. 4, pp. 243-258.

Pickering, A. (1995) The Mangle of Practice: Time, Agency, and Science, Chicago, University of Chicago Press.

Piekut, B. (2014) 'Actor-Networks in Music History: Clarifications and Critiques', Twentieth-Century Music, vol. 11, no. 2, pp. 191-215.

Rai, A. (2013) 'Sound, Perception and Mobile Phones in India', in Ubiquitous Musics: The Everyday Sounds That We Don't Always Notice, ed M. G. Quiñones et al., Farnham, Ashgate.

Read, O. \& Welch, W. (1976) From Tin Foil to Stereo: Evolution of the Phonograph, New York, H.W. Sams.

Rehding, A. (2002) 'Eco-musicology', Journal of the Royal Musical Association, vol. 
127 , no. 2 , pp. 305-320.

Ríos, K. (2011) ‘In Age of Digital Music, Vinyl Gets Second Life in Brooklyn Factory’, New York Times (17 April), online.

Robbins, P. (2012) Political Ecology: A Critical Introduction, Oxford, Blackwell.

Roy, E. (2013) 'Digital Wastelands: Materiality Between Salvation and Oblivion', presented at Music, Digitization, Mediation Conference, University of Oxford, July.

Roy, E. (2014) 'All the Memory in the World, All the Music in the World: Mediating Musical Patrimony in the Digital Age', Networking Knowledge, vol. 7, no. 2, pp. 20-33.

Santoro, M. (2015) 'Production Perspectives', in The Routledge Reader on the Sociology of Music, ed. J. Shepherd and K. Devine, New York, Routledge.

Savage, M. and M. Gayo (2011) 'Unravelling the Omnivore: A Field Analysis of Contemporary Musical Taste in the United Kingdom', Poetics, vol, 39, no. 5, pp. 337357.

Scaping, P. ed (1979) BPI Year Book 1979: A Review of the British Record and Tape Industry, Wadford, British Phonograph Industry. 
Schafer, R. M. (1994) The Soundscape: Our Sonic Environment and the Tuning of the World, Rochester, Destiny Books.

Shields, R. (2012) 'Cultural Topology: The Seven Bridges of Königsburg, 1736', Theory, Culture and Society, vol. 29, no. 4-5, pp. 43-57.

Shuker, R. (2010) Wax Trash and Vinyl Treasures: Record Collecting as a Social Practice, Farnham, Ashgate.

Slade, G. (2006) Made to Break: Technology and Obsolescence in America, Cambridge, Harvard University Press.

Smith, M. (2012) ‘Beck’s Song Reader’, The Culture Show, vol. 21 (28 November), BBC 2.

Sousa, J. P. (1906) 'The Menace of Mechanical Music', Appleton's Magazine, vol. 8, pp. 278-284.

Stanbridge, A. (2007) 'The Tradition of all the Dead Generations: Music and Cultural Policy', International Journal of Cultural Policy, vol. 13, no. 3, pp. 255-271.

Stanyek, J. \& Piekut, B. (2010) 'Deadness: Technologies of the Intermundane', The Drama Review, vol. 54, no. 1, pp. 14-38. 
Starosielski, N. (2012) “"Warning: Do Not Dig”: Negotiating the Visibility of Critical Infrastructures', Journal of Visual Culture, vol. 11, no. 1, pp. 38-57.

Sterne, J. (2003) The Audible Past: Cultural Origins of Sound Reproduction, Durham, Duke University Press.

Sterne, J. (2006a) 'The Death and Life of Digital Audio', Interdisciplinary Science Reviews, vol. 31, no. 4, pp. 338-345.

Sterne, J. (2006b) 'The MP3 as Cultural Artifact', New Media and Society, vol. 8, no. 5, pp. $825-842$.

Sterne, J. (2008) 'The Preservation Paradox in Digital Audio', in Sound Souvenirs: Audio Technologies, Memory and Cultural Practices, ed K. Bijsterveld and J. van Dijck, Amsterdam, Amsterdam University Press.

Sterne, J. (2012) MP3: The Meaning of a Format, Durham, Duke University Press.

Sterne, J. (2013) 'What Do We Want? Materiality! When Do We Want It? Now!' in Media Technologies: Essays on Communication, Materiality and Society, ed T. Gillespie et al., Cambridge, MIT Press. 
Stokes, M. (2004) 'Music and the Global Order', Annual Review of Anthropology, vol. 33, pp. 47-72.

Strasser, S. (1999) Waste and Want: A Social History of Trash, New York, Holt.

Strauss, N. (1995) 'Pennies That Add Up to \$16.98: Why CDs Cost So Much', New York Times (5 July), online.

Straw, W. (1999) 'The Thingishness of Things', Invisible Culture, vol. 1, no. 2, online.

Straw, W. (1999-2000). 'Music as Commodity and Material Culture', Repercussions, vol. 7-8, pp. 147-172.

Straw, W. (2000) 'Exhausted Commodities', Canadian Journal of Communication, vol. 25, no. 1 , pp. 175-185.

Straw, W. (2009) 'In Memoriam: The Music CD and Its Ends', Design and Culture, vol. 1, no. 1 , pp. 79-92.

Straw, W. (2010) 'The Circulatory Turn', in The Wireless Spectrum: The Politics, Practices and Poetics of Mobile Media, ed B. Crow et al., Toronto, University of Toronto Press. 
Straw, W. (2012) 'Music and Material Culture', in The Cultural Study of Music: A

Critical Introduction, ed M. Clayton et al., New York, Routledge.

Street, J. (2013) 'Music, Markets and Manifestos', International Journal of Cultural Policy, vol. 19, no. 3, pp. 281-297.

Suchman, L. (2007) Human-Machine Reconfigurations: Plans and Situated Actions, Cambridge, Cambridge University Press.

Sundaram, R. (2010) Pirate Modernity: Delhi's Media Urbanism, Abingdon, Routledge.

Swadeshi International Co. (2011) ‘The Shellac Story’, online (www.shellac.in).

Taussig, M. (1993) Mimesis and Alterity: A Particular History of the Senses, New York, Routledge.

Taylor, T. (2007a) 'The Commodification of Music at the Dawn of the Era of “Mechanical Music", Ethnomusicology, vol. 51, no. 2, pp. 281-305.

Taylor, T. (2007b) Beyond Exoticism: Western Music and the World, Durham, Duke University Press.

Théberge, P. (1997) Any Sound You Can Imagine: Making Music / Consuming 
Technology, Middletown, Wesleyan University Press.

Thompson, M. (1979) Rubbish Theory: The Creation and Destruction of Value, Oxford, Oxford University Press.

Thompson, R. C. et al. (2009) 'Our Plastic Age', Philosophical Transactions of the Royal Society B: Biological Sciences, vol. 364, no. 1526, pp. 1973-1976.

Toynbee, J. and B. Dueck, eds. (2011) Migrating Music, Abingdon, Routledge

Traiman, S. (1979) 'Tape Products Rocked by Higher Oil Costs', Billboard (14 April), pp. 1,80 .

Traiman, S. (1995) 'Confronting the Cost Demon', Billboard (11 March), pp. 74, 90.

Truax, B. (2001) Acoustic Communication, Westport, Ablex.

Türk, V. et al. (2003) The Environmental and Social Impacts of Digital Music: A Case Study with EMI, Brussels, Digital Europe.

Vanderbilt, B. (1971) Thomas Edison, Chemist, Washington, American Chemical Society. 
Walker, P. \& Steele, L. (1922) 'Shellac', Technological Papers of the Bureau of

Standards, vol. 17, pp. 277-296.

Weber, C. et al. (2010) 'The Energy and Climate Change Implications of Different Music Delivery Methods', Journal of Industrial Ecology, vol. 14, no. 5, pp. 754-769.

Winner, L. (1944) 'Shellac and Development of Substitutes', Plastics, vol. 1, no. 2, pp. $55-56,96$.

Wittchen, S. (2012) 'Recycling Challenge: Vinyl Records', Grid Magazine, vol. 43, p. 7. 